\title{
HOW HUMAN RESOURCES MANAGEMENT PRACTICE AND CHANGE MANAGEMENT CONTRIBUTE TO THE SMALL MEDIUM ENTERPRISES PERFORMANCE
}

\author{
Bagus Kusuma ${ }^{1}$, Andhika Kautsar ${ }^{2}$ \\ ${ }^{1}$ Sekolah Tinggi Manajemen Informatika dan Komputer-Indonesia \\ ${ }^{2}$ School of Business and Management, Institut Teknologi Bandung \\ Email: baguskus@gmail.com
}

How to cite (in APA style):

Kusuma, B., \& Kautsar, A. (2020). How Human Resources Management Practice and Change Management Contribute To The Small Medium Enterprises Performance. Warmadewa Management and Business Journal 2(1), pp.41-47.

\begin{abstract}
SMEs (small and medium enterprises) food \& beverage is one type of business that plays a role in improving the economy in Indonesia. This research has a goal to explore for some owner/manager of SMEs in managing change, recognizing the importance of the people within the company, and knowing the ability of the owner/manager of SMEs in adapting and developing new learning and skill. The observation is conducted in Bandung with an indepth interview and questionnaire method to 30 respondents involving 10 SME owners/managers in in-depth interview. The analysis of the mixed method finds that the solution of the existing issue of change management needs to be done to help the occurrence of change management. Therefore, the system in the company concerned with human resources can be improved so that talent management will be more efficient and targeted.
\end{abstract}

Keywords: SME, food and beverage industry, performance, change management, talent management

\section{INTRODUCTION}

Small and medium enterprises (SMEs) are one type of business that plays a role in encouraging economic growth in Indonesia. With the sector of unemployment, SMEs absorb workforce to the world of work. SME Sector has also proven to be a pillar of a tough economy. Husband and Purnendu ini (Tambunan, 2005) describes the crucial development of SMEs because it has been a key and important player in the economic development of a country. SME development is intensified by the government and related parties to improve performances in this sector. SMEs have an important role in the economy in Indonesia. There are 697,328 units of SMEs in Indonesia which contribute $36.90 \%$ to Gross Domestic Product or equivalent to Rp. 2,113.4 trillion with the ability to absorb the workforce of 9,519,616 people and a considerable contribution to the investment of Rp. 1,469.5 Trillion (Kemenkop SME, 2018).

The industry of F\&B continues to experience changes/developments in the world, including in Indonesia. In Bandung itself, culinary industries are growing rapidly, can be seen from the number of restaurants, cafes, even new food trucks that keep popping up in various regions, especially in downtown area. Bandung has the largest number of food $\&$ beverages industry in west java that shown in table 1.1. 
Table 1. 1 Number of restaurants in Bandung

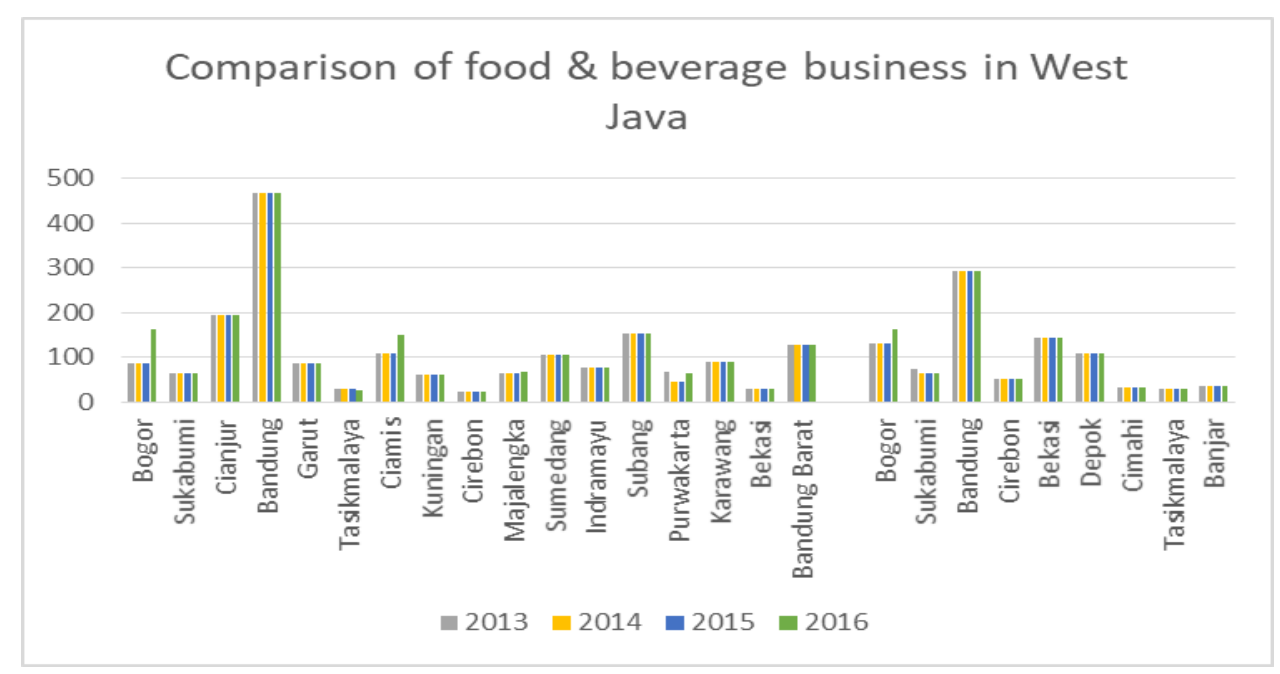

\section{Source: Dinas Pariwisata dan Kebudayaan Jawa Barat}

Trend changes in various dimensions cannot be avoided; there is always an effect on the organization of the company. Change management becomes very important to implement. However, in reality, the process of change does not always get positive responses. In its application, there are those who love change and who do not like it. Managers need to understand why organizations should be prepared for changes (innovative and strategic changes). The managers/owners of the SME companies are required to proactively explain to the employees about the change of strategy within the company to be undertaken. At least, owners and managers of SMEs understand the strategy that they create before it is given to their employees. In addition, improving performances through innovation is one way a company, especially SME, can compete in the current market competition.

The problems of this research that arises into three main question how able SMEs owners/managers manage the change, how do SME owners/managers recognize the importance of the people within the firm, and how able are the SMEs owners/managers to adapt and develop new skills? All of the questions are asked in this research to find out what activities are done by SME companies to improve the effectiveness and probability of their companies.

\section{LITERATURE REVIEW}

\section{Human Resource Management (HRM)}

Human Resource Management (HRM) is part of organizational management that focuses on the human element (Umar, 2007). HRM's main focus is to contribute to the success of the company. According to (Hariandja, 2017), the scope of HRM includes all activities related to employees within the company covering all activities related to employees within the company that include organizational design, reward system, employee and organizational development, communications and public relations, and performance.

\section{Change Management}

The process of continually renewing a direction of structure's organization and capabilities in the serve of an ever-changing need of external and internal customer are defined by Change Management (Moran, J. W., \& Brightman, 2001). Change Management is a structured and strategic approach to manage and initiate the changes process in the organization structure and 
culture as well as the individuals/ teams behaviour and attitude toward the change transition in the field of the business processes, technology implementation of any other policies of an enterprise (Burnes, 2004).

Change Management involves processes such as planning for change, managing change and reinforcing change. Change Management provides tools to realize for example, individual change model, communications, coaching, sponsorship, training, and resistance management. Each tool is trying to achieve its goal. All these tools should be integrated in organization's structure of job role and need structure to manage technical side and people side (McCarthy, 2010).

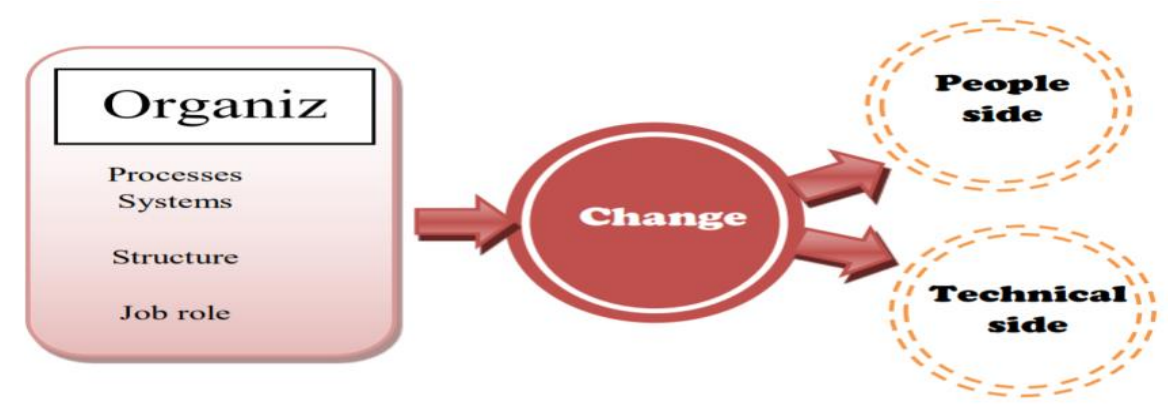

Figure 2.1 Change focuses on People and technical sides (Munasar et al, 2013)

According Munasar et al (2013), there are several phases where change should go through to ensure the smoothness of Change Management implementation.

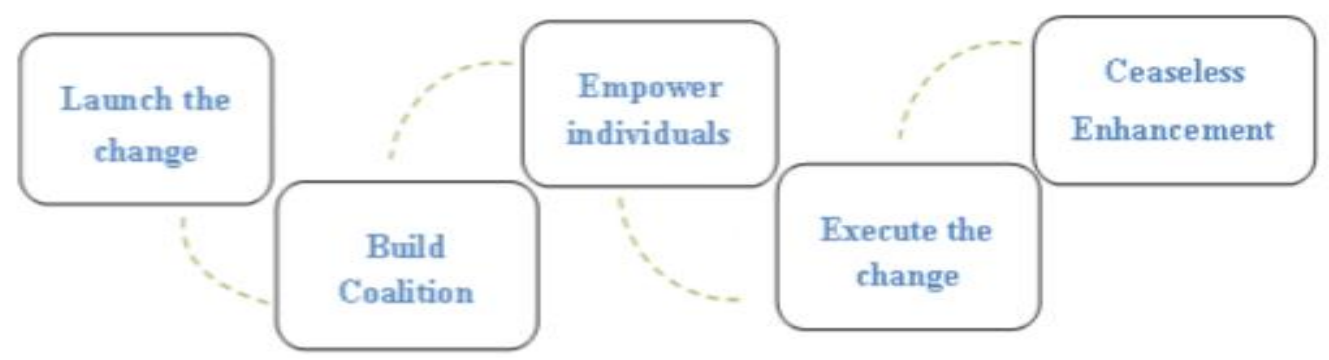

Figure 2.2 Change Management Framework (Munasar et al, 2013)

\section{METHOD}

In this research, researcher use Explanatory Sequential Mixed Methods (Creswell, 2014). The first step will be explained by qualitative data to collect and analyse the data by the Indepth Interview, and the second tools will be followed by quantitative research to support the qualitative data. Explanatory Sequential Mixed Methods on this research will be using two steps: The first method use qualitative data that were collected by CGTC (Conceptualising Growth in a Transition Context) and the result of In-depth Interview will be supported by quantitative data were collected by PSP (Promoting Sustainable Performance) questionnaires.

In this research, researcher use Within Case Analysis and Cross Case Analysis to analyse the In-depth Interview. According to (Yin, 2003)with using Within Case Analysis and Across Case Analysis it could get the ability to explore the subunits that are located within larger case. The analysis should be easy to understand to fulfil the research purpose, and the benefit of 
those analyses make deeper understanding of the exploring objects/issues (Gustafsson A., 2017)

Table 3.1 List of In-depth Interview respondents

\begin{tabular}{|c|l|l|l|}
\hline No & \multicolumn{1}{|c|}{ F\&B SME } & \multicolumn{1}{c|}{ Field(s) } & \multicolumn{1}{c|}{ Informant(s) } \\
\hline 1 & Stream Coffee & Coffee Shop & Dhika Syafri (Manager) \\
\hline 2 & Summercupcakes & Cake-house & Felicia Elsa (Owner) \\
\hline 3 & Aruna Coffee \& Dine & Coffee Shop & Azmi Ghifari (Owner) \\
\hline 4 & Sunnyside & Coffee Shop & Adityo (Owner) \\
\hline 5 & Joyful & Frozen Food & Octaviani (Owner) \\
\hline 6 & Steak Ranjang & $\begin{array}{l}\text { Steak } \\
\text { Restaurant }\end{array}$ & Aditia (Owner) \\
\hline 7 & SeblakMommyindo & Instant Food & Seinda (Owner) \\
\hline 8 & BebekGarang & Restaurant & Ali Bagus (Owner) \\
\hline 9 & Siomay Mayo-curshty & Instant Food & Andri Harianto (Owner) \\
\hline 10 & Tempe Krezi & Snack & I Nyoman (Owner) \\
\hline
\end{tabular}

Research analysis will be conducted in 2 steps, first is to analyse the In-depth Interview using Within Case Analysis and Across Case Analysis regarding to Change Management and Talent Management issues, and second is to prove the desire of SMEs in Growth and Development by Analyse the Questionnaires, so the solution will be more specific about the issues and the SMEs' desires. In addition to interviews, this research also used a Questionnaire. In addition to In-depth Interviews, this research also using Questionnaire. The Questionnaire involved 30 respondents of $\mathrm{F} \& \mathrm{~B}$ owners/managers located in Bandung city. The respondents are:

Table 3.2 List of Questionnaire respondents

\begin{tabular}{|c|l|}
\hline No & \multicolumn{1}{|c|}{ Company Name } \\
\hline 1 & Stream Coffee \\
\hline 2 & Summercupcakes \\
\hline 3 & Aruna Coffee \& Dine \\
\hline 4 & Sunnyside \\
\hline 5 & Joyful \\
\hline 6 & Steak Ranjang \\
\hline 7 & Seblak Mommyindo \\
\hline 8 & BebekGarang \\
\hline 9 & Siomay Mayo Crusty \\
\hline 10 & Tempe Krezi \\
\hline 11 & Amisae \\
\hline 12 & Angkringan Narji \\
\hline 13 & ZEB Store \\
\hline 14 & Gudeg Jogja Bu nesti \\
\hline 15 & Sate Klatak Mas Tanto \\
\hline
\end{tabular}

\begin{tabular}{|c|l|}
\hline No & \multicolumn{1}{|c|}{ Company Name } \\
\hline 16 & Cupa-cupa Snack \\
\hline 17 & Sate Taichan Buah Batu \\
\hline 18 & Sucre Patissier \\
\hline 19 & CirengMangAup \\
\hline 20 & Takemecakes \\
\hline 21 & Queenz Recipe \\
\hline 22 & Chicken Little Party \\
\hline 23 & Infinito Culinary \\
\hline 24 & Depok Mengunyah \\
\hline 25 & Dabelyuw Kitchen \\
\hline 26 & dMoners Home \\
\hline 27 & Nangkring \\
\hline 28 & Ravena Cookies \\
\hline 29 & Boom Nam Authentic Thai tea \\
\hline 30 & Amoa Herb \\
\hline
\end{tabular}


In this research the qualitative approach consists of two methods: Within Case Analysis and CrossCase Analysis, each method has a purpose that explains on Table 3.3.

\section{Table 3.3 Within and Across Case Analysis Strategies}

\begin{tabular}{|l|l|l|}
\hline \multicolumn{1}{|c|}{ Analytic Focus } & \multicolumn{1}{|c|}{ Strategy } & \multicolumn{1}{c|}{ Product } \\
\hline Within Each Cases & Focus in each interview. & $\begin{array}{l}\text { Identification of significant } \\
\text { statements. }\end{array}$ \\
\hline Across Cases & $\begin{array}{l}\text { Comparison of significant } \\
\text { statements. }\end{array}$ & $\begin{array}{l}\text { Identify categories of } \\
\text { statements common to all } \\
\text { participants }\end{array}$ \\
\hline $\begin{array}{l}\text { Set of Significant } \\
\text { Statements }\end{array}$ & $\begin{array}{l}\text { Organization of categories } \\
\text { of significant statements } \\
\text { by themes. }\end{array}$ & Essential structure. \\
\hline $\begin{array}{l}\text { Essential Structure, } \\
\text { Summaries of } \\
\text { Themes }\end{array}$ & $\begin{array}{l}\text { Essential structures, } \\
\text { summaries of themes. }\end{array}$ & Intensification. \\
\hline
\end{tabular}

Source: Ayres et al, 2003

\section{RESULTS AND DISCUSSION}

Change in firms, and especially in small entrepreneurial firms is a challenging issue. According to (Strebel, 1996) the success rates are well below 50\% and (Burnes, 2004) claim to have evidence that about $70 \%$ of all change initiatives fail. Because Change Management is important for organizations, being able to implement change successfully is a much-wanted skill (Senior, B., \& Fleming, 2006). However, it is also one of the least understood skills of managers (Armenakis, A., \& Harris, 2002). One of the change management way that can be implemented by SMEs is Kurt Lewin three steps theory (Lewin, 1951). At this theory Kurt Lewin planned approach to change comprised four elements: Field Theory, Group Dynamics, and Action research and 3step model of change. Kurt Lewin proposed a three-stage theory of change commonly referred to as Unfreeze, Change (or Transition), Freeze (or Refreeze).

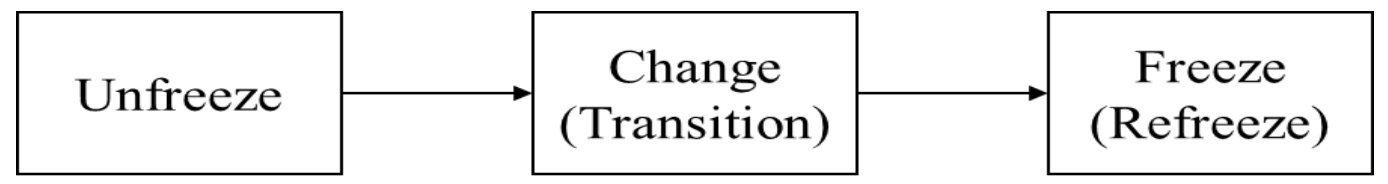

Figure 3. 1 Kurt Lewin Model of Change

Lewin conceived of this as one part, along with Field Theory, Group Dynamics and Action Research, of an integrated approach to analyzing, understanding and bringing about change plane at the group, organizational and societal levels (Lewin, 1951). To change management Lewin's theory believed a successful change project involved three steps: 
Step 1: Unfreezing. Lewin argued that changing the human behaviour is a very challenging process. In this study, the SME owner/manager have to change their perspective about training and development and start to be considering the long-term strategy about these. This step would not be easy or that the same techniques could be applied in all situation.

Step 2: Change (transition). Unfreezing creates motivation to learn but does not necessarily control or predict the direction. It is necessarily to consider all the forces at work, and identify and evaluate, iteratively, the available option (Allport, 1948). This action Research-based learning approach enables groups and individuals to move to a more acceptable set of behaviours. In this step SMEs owner/manager can involve to organization to explore, sharing, and brainstorming the idea/knowledge, because in the search of idea, external parties will give the different perspective about ideas/knowledge.

Step 3: Freeze (refreezing). This seeks to stabilize the group at the new mind-set in order to ensure that the new behaviours are relatively safe from regression. The new behaviour must be, to some degree, congruent with the rest of the behaviour, personality and environment of the leaner or it will simply lead to a new round of disconfirmation (Schein, 1996). At this step SMEs begin to implement new custom habits that exist within the company.

\section{CONCLUSION}

In the name of business practice, there will be a change of trend. Change management becomes an important part when companies make changes in their day-to-day operations. Change management is a strong control of the transfer system from the development stage. As a business actor, the owners/managers of SMEs should be able to adapt this with the holding of Training \& Development (T\&D) for employees, it is also done to improve the knowledge and productivity of employees within an SME company.

Employees are one important asset for SMEs in addition to the products presented and it is impossible for a company to run only managed by the owner/manager only. Every employee needs to feel that what he does is important. No matter how low the status they are at the time. They have to feel that what they do has an impact on the other aspects (in one company).

Surely this is not apart from basic human needs that one wants to be considered important, it is encouraging to owners/managers of SMEs to give appreciation to the success of all employees within a company. In the daily work implementation, employees receive various inputs regarding the implementation of work and try to solve various problems that arise, so that in terms of life, employees receive information or act as perpetrators of all activities undertaken within the company then they have obtained the ability to work (Mathis \& Jackson, 2006). 


\section{REFERENCES}

Allport, G. W. (1948). The Genius of Kurt Lewin. Journal of Social Science, 4(12), 14-21.

Armenakis, A., \& Harris, S. (2002). Crafting a change message to create transformational readiness. Journal of Organizational Change Management, 15(2), 169-183.

Burnes, B. (2004). Kurt Lewin and complexity theories: back to the future? Journal of Change Management, 4(4), 309-325.

Creswell, J. W. (2014). Research Design: Qualitative, Quantitative and Mixed Methods Approaches (4th ed.). Thousand Oaks, CA: Sage.

Gustafsson A. (2017). Assessing work order information quality in harvesting. Silva Fennica, $51(4)$.

Hariandja, M. E. (2017). Manajemen Sumber Daya Manusia: Pengadaan, Pengembangan, Pengkompensasian, dan Peningkatan Produktivitas Pegawai. Jakarta, Gramedia.

Lewin, K. (1951). Field Theory in Social Science. Haarper \& Row.

Mathis, R. L., \& Jackson, J. . (2006). Human Resource Management: Manajemen Sumber Daya Manusia. Terjemahan Dian Angelia. Salemba Empat.

McCarthy, M. P. (2010). Climate change in cities due to global warming and urban effects. Geophysical Research Letter.

Moran, J. W., \& Brightman, K. (2001). Leading organizational change. Career Development International, 6(2), 111-119.

Schein, E. H. (1996). Culture: The missing concept in organization studies. Administrative Science Quarterly, 41(2), 229-240.

Senior, B., \& Fleming, J. (2006). Organizational Change. London: Prentice Hall.

Strebel, P. (1996). Why Do Employees Resist Change? Harvard Business Review, 74, 86-92.

Tambunan, T. (2005). Promoting Small and Medium Enterprises with a Clustering Approach: A Policy Experience from Indonesia. Journal of Small Business Management, 43(2), 138154.

Umar, H. (2007). Riset Sumber Daya Manusia. PT Gramedia Widiasarana. Jakarta.

Yin, R. K. (2003). Case Study Research: Design and Methods. Thousand Oaks, California. 